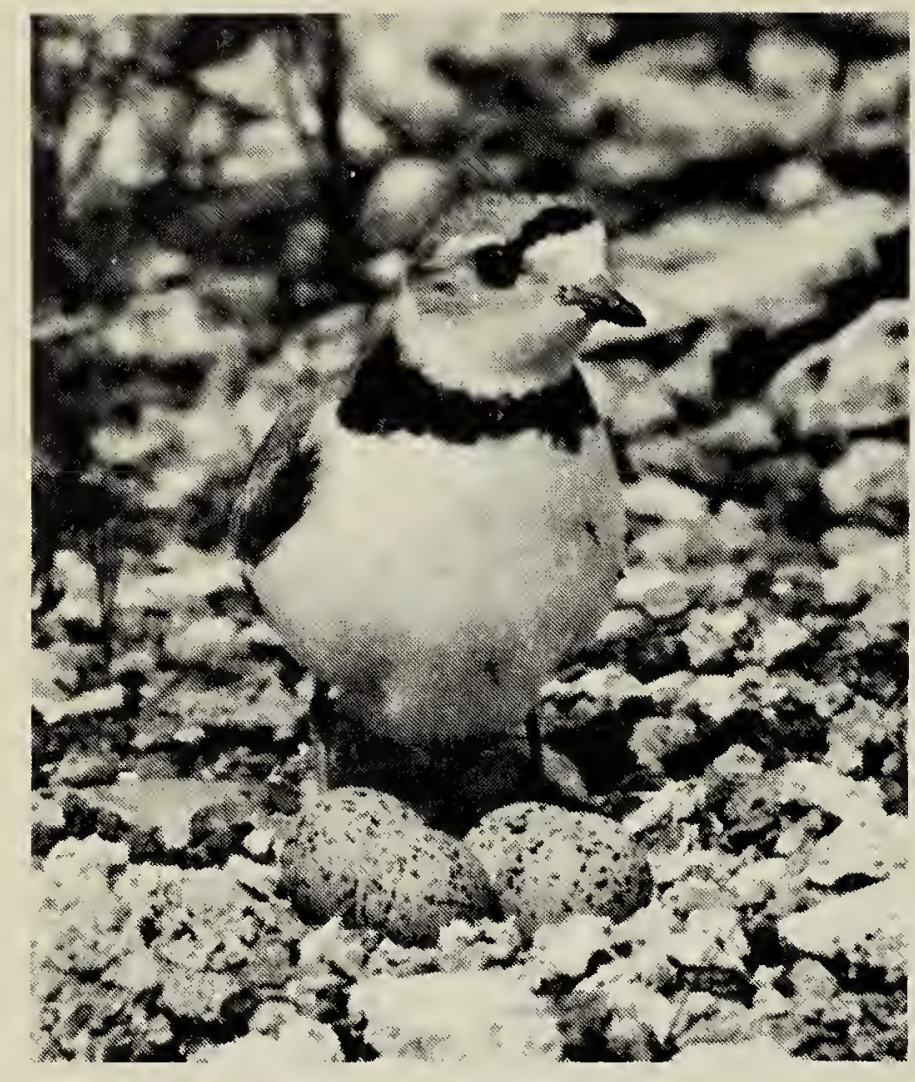

Piping Plover

R. E. Gehlert

\section{PIPING PLOVER NESTING AT DIEFENBAKER LAKE, SASKATCHEWAN}

by PAUL C. RUMP*

I was most interested to read Wayne Renaud's report on nesting records for the Piping Plover in Saskatchewan, which was published in the September issue of Blue Jay.

I would like to add Lake Diefenbaker as another breeding locality for this species. One of my favourite camping spots is on the west side of the Qu'Appelle Arm of Lake Diefenbaker. In 1974 we visited this sand dune area on the weekend of June 15 and 16. On the $16 \mathrm{th}$, while on a shoreline walk with my family, we discovered two nests of the Piping Plover. The nests, which were about $1 / 2$ mile apart, were located about 2 miles southeast of the former rail point of Aiktow. The nests were within pebble patches on the otherwise sandy beach. Each nest contained four eggs. The eggs were very well camouflaged amongst the pebbles

\footnotetext{
*3320 Angus Street,
}

Regina, Saskatchewan.

S4S IP8 and we had to wait patiently at distance for the birds to return to the nest before we eventually pinpointed and found them. At the second nes site, the adult bird went through an elaborate broken wing display to try ti lure us from the nest. This, the camouflaged eggs, and the simple nes were ideal learning experiences for $\mathrm{m}$ y young children.

\section{SHRIKE CAPTURES BLACKBIRD}

\author{
by S. O. JORDHEIM*
}

During the fall and winter month we are visited occasionally by the Nor thern Shrike which preys on Hous Sparrows around the yard. On Octobe 30,1974 . I was surprised to see on ignore the sparrows which were cir cling in a dense group and give chas to a Rusty Blackbird.

At first the blackbird kept a health lead and did not seem perturbed abot its pursuer, but the shrike kef doggedly on and, when getting close would try to grasp the blackbird whic would then put on a burst of speed an get a lead of 20 to 30 feet. The chas continued around the yard and pastur several times at a height of 25 to 4 feet and, I would estimate, a distang of 2.5 to 3 miles. The blackbird w: tiring but the shrike seemed to $g$ stronger making more frequent a tempts to capture his victim. Final the shrike grasped it in the air an both birds plunged to the ground.

I was surprised to see the shrike a tempt to capture an apparently health bird of this size. At no time did th blackbird attempt to get into trees bushes as the sparrows do.

On another occasion a shrike ca tured a House Sparrow about $20 \mathrm{fe}$ from where I was standing. It ve quickly killed it by biting it in tl throat area and then, seeing me, hasti flew away carrying its prey with $i$ feet, the same as a hawk does.

\footnotetext{
*White Bear, Saskatchewan.
} 